\title{
Raw and calcination-modified coal waste as adsorbents to remove cadmium from simulated mining wastewater
}

\author{
M. Zhang $\cdot$ H. Wang
}

Received: 6 August 2012/Revised: 19 March 2013/Accepted: 23 April 2013/Published online: 17 May 2013

(C) Islamic Azad University (IAU) 2013

\begin{abstract}
The adsorption of cadmium from simulated mining wastewater by coal waste (CW) and calcinationmodified coal waste (MCW) was investigated. Effects of $\mathrm{pH}$, initial concentration, particle size of adsorbent, adsorbent dosage and temperature were studied in batch experiments. The adsorption efficiency for cadmium increased with increasing $\mathrm{pH}$, and the optimum $\mathrm{pH}$ for cadmium adsorption onto MCW and $\mathrm{CW}$ was 6.0 and 6.5, respectively. Kinetic experiments showed that the adsorption equilibrium was reached within $120 \mathrm{~min}$ and followed pseudo-second-order model well. The adsorption isotherm data fit Langmuir and Freundlich models, and the adsorption capacity of cadmium on the two adsorbents increased with increasing temperature from 298 to $318 \mathrm{~K}$. MCW had a higher adsorption capacity of cadmium than $\mathrm{CW}$, because calcination treatment can make $\mathrm{CW}$ to have more loose structure and higher specific surface area. Thermodynamic parameters, the Gibbs free energy change $\left(\Delta G^{0}\right)$, enthalpy change $\left(\Delta \mathrm{H}^{0}\right)$ and entropy change $\left(\Delta \mathrm{S}^{0}\right)$, were calculated and the results showed that the adsorption of cadmium on $\mathrm{CW}$ and MCW was spontaneous and endothermic. Fourier transform infrared studies indicated silanol and aluminol groups were responsible for cadmium binding. The desorption results indicated that the two adsorbents could be used repeatedly at least three times without significant decrease in the adsorption capacity for cadmium. The results suggested that modified $\mathrm{CW}$ could have high potential as low-cost adsorbent for cadmium removal.
\end{abstract}

M. Zhang $(\bowtie) \cdot H$. Wang

School of Resources and Environment, University of Jinan, Jinan 250022, China

e-mail: stu_zhangml@ujn.edu.cn
Keywords Adsorption - Desorption · Heavy metal · Thermodynamic parameters

\section{Introduction}

The release of heavy metals into aquatic ecosystems has caused serious environmental problems because of their toxicity, non-biodegradation and the tendency for accumulation in the food chain (Zhao et al. 2011a, b). Among heavy metals, cadmium is an extremely toxic metal, which is usually found in wastewater from mining, metal plating, smelting, batteries, phosphate fertilizers, pigments, stabilizers, plastics and other industrial process. Excessive exposure to cadmium can cause harmful effects on human health, including itai-itai disease, emphysema, kidney damage and renal damage (Zhu et al. 2007; Munagapati et al. 2010). Therefore, many methods have been developed to remove cadmium from aqueous solution such as chemical precipitation, membrane separation, ion exchange and electrochemistry removal. However, the application of such treatment methods is often restricted because of economic or technical constraints. Adsorption by using low-cost materials is one of the most promising methods to remove heavy metal from wastewater. Many agricultural, industrial and natural waste materials have been used as adsorbents in recent years (Ajmal et al.1998; Gupta and Ali 2004; Villaescusa et al. 2004; Qin et al. 2006; Amuda et al. 2007; Dias et al. 2007; Aydin et al. 2008; Pehlivan et al. 2009; Sthiannopkao and Sreesai 2009; Zvinowanda et al. 2009; Suresh et al. 2012; Zamani et al. 2013), but there are few reports on the application of raw or modified coal waste (CW) in the removal of heavy metal from simulated coal mine wastewater.

There are large amounts of CW generated during coal excavation and subsequent washing processes, which have 
accumulated to nearly 8.0 billon tons at present, and are approaching 380 million tons annually in China. Many CW piles are formed because utilization is usually $<30 \%$. Moreover, a large amount of mining wastewater containing heavy metals can be discharged in the coal mining process, which can result in serious pollution to surrounding soil and water. It will be ideal if the coal mining wastewater containing heavy metals can be treated by physically and/ or chemically altered forms of coal waste, and this is just the objective of our present study.

Considering that the chemical activity and adsorption capacity of CW may be improved by calcination treatment, calcination-modified coal waste (MCW) was examined to be one potential low-cost adsorbent in this study. The potential of $\mathrm{CW}$ and $\mathrm{MCW}$ to remove $\mathrm{Cd}(\mathrm{II})$ from coal mining wastewater was evaluated through a series of batch experiments. The effects of $\mathrm{pH}$, initial concentration, adsorbent dosage, particle size of adsorbents and temperature on the adsorption capacity were investigated. Adsorption isotherm models and thermodynamic parameters were also studied to understand the adsorption characteristics. The objective of this study was to establish a fundamental understanding of the adsorption behavior of $\mathrm{Cd}(\mathrm{II})$ on $\mathrm{CW}$ and $\mathrm{MCW}$, in order to provide a basis for their practical application to mining wastewater treatment. This work was conducted from October to December 2011, in Univeristy of Jinan, China.

\section{Materials and methods}

\section{Materials}

Coal waste $(\mathrm{CW})$ used in this study was obtained from Zhaolou coal mine in Yuncheng County, Shandong province, China. The adsorbents were ground, dried at $105{ }^{\circ} \mathrm{C}$ for $12 \mathrm{~h}$ and then stored in a plastic container prior to use. In order to study the effect of calcination modification of $\mathrm{CW}$ on the adsorption of $\mathrm{Cd}(\mathrm{II})$, one portion of $\mathrm{CW}$ sample was calcinated in a furnace at $700{ }^{\circ} \mathrm{C}$ for $2 \mathrm{~h}$, cooled in air and then stored in a plastic container as calcination MCW adsorbent in the following experiments (Kakali et al. 2001; Kuang et al. 2012).

All regents used in the present study were all of analytical grade. The stock solution of $\mathrm{Cd}(\mathrm{II})\left(10 \mathrm{mmol} \mathrm{L}^{-1}\right)$ was prepared by dissolving $\mathrm{Cd}(\mathrm{II})\left(\mathrm{NO}_{3}\right)_{2} \cdot 4 \mathrm{H}_{2} \mathrm{O}$ and then diluted to appropriate concentrations. A total of $0.5 \mathrm{~mol} \mathrm{~L}^{-1} \mathrm{HNO}_{3}$ and $\mathrm{NaOH}$ were used for $\mathrm{pH}$ adjustment in adsorption experiments, and $0.1 \mathrm{~mol} \mathrm{~L}^{-1} \mathrm{HCl}$ was used as the desorption agent in the desorption experiments. $0.05 \mathrm{~mol} \mathrm{~L}^{-1} \mathrm{NaNO}_{3}$ was used as background electrolyte.
Methods

\section{Characteristics of adsorbents}

The $\mathrm{pH}$ of adsorbent pastes was measured by $\mathrm{pH}$ meter (Delta320 METTLER, Germany) in a 1:5 (w/v) solid/water suspension for $24 \mathrm{~h}$ to reach equilibrium. The point of zero charge $\left(\mathrm{pH}_{\mathrm{PZC}}\right)$ was determined using the solid addition method (Tripathy and Kanungo 2005). The specific surface area of the adsorbents was measured by the $\mathrm{N}_{2}$ gas adsorption method with the data BET analysis (Micromeritics, ASAP 2020, USA). Surface morphology of the adsorbents was examined by a scanning electron microscope (SEM, Quanta FEG 250). The SEM was equipped with an energy dispersion spectrometer (EDS, X-Max50), which was used to analyze the chemical constituents of the adsorbents before and after adsorption of Cd(II). Fourier transform infrared (FTIR) spectrometery (RX-1, PerkinElmer, USA) was used to determine functional groups of the two adsorbents before and after Cd(II) loading in the wavenumbers range of $400-4,000 \mathrm{~cm}^{-1}$. The FTIR spectra of the samples prepared as $\mathrm{KBr}$ pellets were recorded on a Perkin-Elmer Model System 2000. X-ray diffraction (XRD) analysis of $\mathrm{CW}$ and $\mathrm{MCW}$ was conducted using powder XRD mounts (D/Max-IIIA, Japan) over a $2 \theta$ interval of $5-70^{\circ}$ with $\mathrm{Cu} \mathrm{K} \alpha$ radiation.

\section{Batch adsorption experiment}

The adsorption experiments were carried out at room temperature $(298 \mathrm{~K})$ in $50-\mathrm{mL}$ flasks by mixing $0.3 \mathrm{~g}$ adsorbent (60-80 mesh, unless otherwise stated) with $20 \mathrm{~mL}$ of $0.2 \mathrm{mmol} \mathrm{L}^{-1} \mathrm{Cd}$ (II) solution using a shaking thermostat machine at a speed of $200 \mathrm{rpm}$ for $120 \mathrm{~min}$, which was found to be enough to reach adsorption equilibrium. The $\mathrm{pH}$ of solution was maintained at 6.0 for $\mathrm{MCW}$ and 6.5 for $\mathrm{CW}$ by addition of drops of $0.5 \mathrm{~mol} \mathrm{~L}^{-1}$ $\mathrm{HNO}_{3}$ or $\mathrm{NaOH}$ solutions, and solution background electrolyte of $0.05 \mathrm{~mol} \mathrm{~L}^{-1} \mathrm{NaNO}_{3}$ was used (unless otherwise stated).

Kinetic studies were conducted by collecting samples at $5,10,20,30,60,120,180,240$ and $720 \mathrm{~min}$ to reveal the contact time for reaching adsorption equilibrium. The effect of solution $\mathrm{pH}$ on the adsorption of $\mathrm{Cd}(\mathrm{II})$ on the adsorbents was investigated in the range of 2.0-7.0, where $\mathrm{Cd}(\mathrm{II})$ precipitation does not occur. The effect of adsorbent dosage was studied by varying the adsorbent dosage from 5 to $50 \mathrm{~g} \mathrm{~L}^{-1}$. Six different particle sizes of the adsorbents (40-60 mesh, 60-80 mesh, 80-100 mesh, 100-120 mesh, 120-140 mesh, and large than 140 mesh) were selected for the study of effect of particle size on Cd(II) adsorption. For 
adsorption isotherm study, $0.3 \mathrm{~g}$ adsorbent was mixed with $20 \mathrm{~mL} \mathrm{Cd}(\mathrm{II})$ solutions at various concentrations (0.05-1.5 mmol L $\left.{ }^{-1}\right)$ and the mixtures were stirred for $120 \mathrm{~min}$ in the temperature range of $298-318 \mathrm{~K}$. After adsorption, the adsorbent was filtered by 0.45 -um filter paper and the concentration of $\mathrm{Cd}(\mathrm{II})$ ions in the solution was analyzed by ICP-OES (Perkin Elme, USA).

The adsorption efficiency of Cd(II) was calculated using Eq. (1) and the adsorption capacity was calculated using Eq. (2).

$R=\frac{\left(C_{\mathrm{o}}-C_{\mathrm{f}}\right)}{C_{\mathrm{o}}} \times 100 \%$

$q=\frac{V\left(C_{\mathrm{o}}-C_{\mathrm{f}}\right)}{m}$

Where $R$ is adsorption efficiency, $q$ is the amount of $\mathrm{Cd}$ (II) sorbed per unit mass of the adsorbent $\left(\mathrm{mmol} \mathrm{g}^{-1}\right)$, $V$ is the solution volume (L), $m$ the weight of the adsorbent $(\mathrm{g}), C_{\mathrm{o}}$ and $C_{\mathrm{f}}$ initial and final $\mathrm{Cd}(\mathrm{II})$ concentration $\left(\mathrm{mmol} \mathrm{L}^{-1}\right)$.

\section{Desorption experiment}

$0.3 \mathrm{~g}$ adsorbents were added into $20 \mathrm{~mL}$ of $0.5 \mathrm{mmol} \mathrm{L}^{-1}$ Cd(II) under the experimental conditions in the batch adsorption described above. After the adsorption equilibrium, the $\mathrm{Cd}(\mathrm{II})$-loaded adsorbents were placed in another flask and mixed with $50 \mathrm{~mL}$ of $0.1 \mathrm{~mol} \mathrm{~L}^{-1} \mathrm{HCl}$ solution for $120 \mathrm{~min}$. The mixture was filtered and the desorbed $\mathrm{Cd}$ (II) was measured in the filtrate. The adsorbents were washed three times with distilled water to remove remaining acid and reused for next adsorption-desorption cycle. The adsorption-desorption processes were repeated three times. All the above experiments on batch adsorption and desorption were carried out in triplicate and the average results were presented in this study.

\section{Results and discussion}

Characteristics of adsorbents

The point of zero charge $\left(\mathrm{pH}_{\mathrm{PZC}}\right)$ of $\mathrm{CW}$ and $\mathrm{MCW}$ was found to be 5.8 and 5.5, and the paste $\mathrm{pH}$ of $\mathrm{CW}$ and $\mathrm{MCW}$ was 8.3 and 8.1, respectively. The SEM micrographs of the two adsorbents are shown in Fig. 1. It can be seen that the surface morphology of MCW was more porous and loose than that of $\mathrm{CW}$ due to calcination treatment. The specific surface area of CW and MCW samples was found to be 3.83 and $9.15 \mathrm{~m}^{2} \mathrm{~g}^{-1}$, respectively, which shows that calcination treatment increased the specific surface area of $\mathrm{CW}$ and favoured higher adsorption capacity for $\mathrm{Cd}(\mathrm{II})$. The XRD analysis in Fig. 2 shows that the main mineral phases of $\mathrm{CW}$ are quartz, kaolinite and illite, while characteristic diffraction peaks for kaolinite disappeared entirely in MCW because kaolinite was converted to amorphous metakaolinite by dehydroxylation when calcinated at around $700{ }^{\circ} \mathrm{C}$ (Kakali et al. 2001; Kuang et al. 2012). So calcination modification can make CW to have loose structure and higher activity of chemical reaction.

The FTIR spectra of CW and MCW are shown in Fig. 3. Stretching vibrations of $\mathrm{OH}-$ in kaolinite was observed at $3,695.96$ and $3,620.19 \mathrm{~cm}^{-1}$, bending vibration of $\mathrm{Al}-\mathrm{OH}$ at $913.77 \mathrm{~cm}^{-1}$, stretching vibrations of $\mathrm{Si}-\mathrm{O}$ at $1,010.21 \mathrm{~cm}^{-1}, 1,034.02$ and $1,091.45 \mathrm{~cm}^{-1}$, bending vibrations of $\mathrm{Si}-\mathrm{O}$ at $471.17 \mathrm{~cm}^{-1}$ and stretching vibrations of $\mathrm{Si}-\mathrm{O}-\mathrm{Al}^{\mathrm{VI}}$ at $538.79 \mathrm{~cm}^{-1}$. The FTIR spectra described above show the characteristic bands of kaolinite
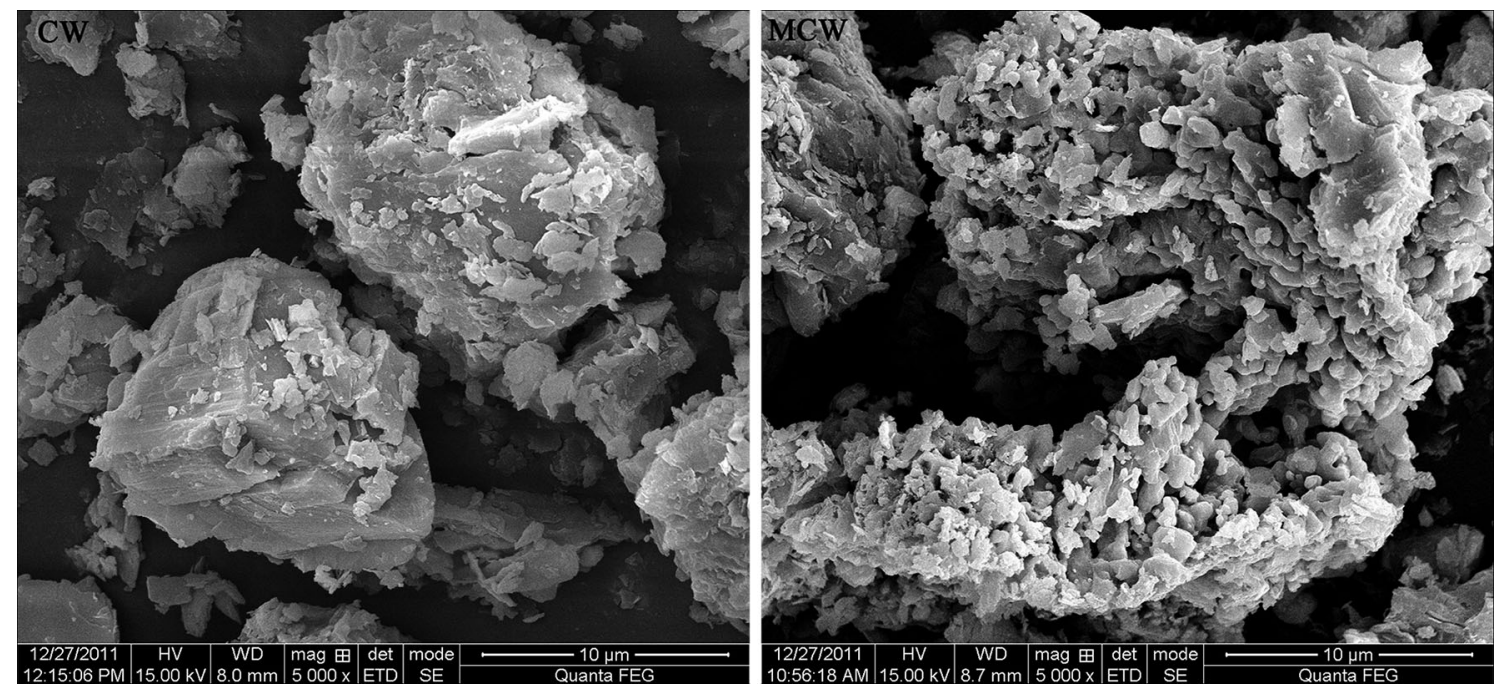

Fig. 1 Scanning electron microscope micrographs of $\mathrm{CW}$ and $\mathrm{MCW}$ 

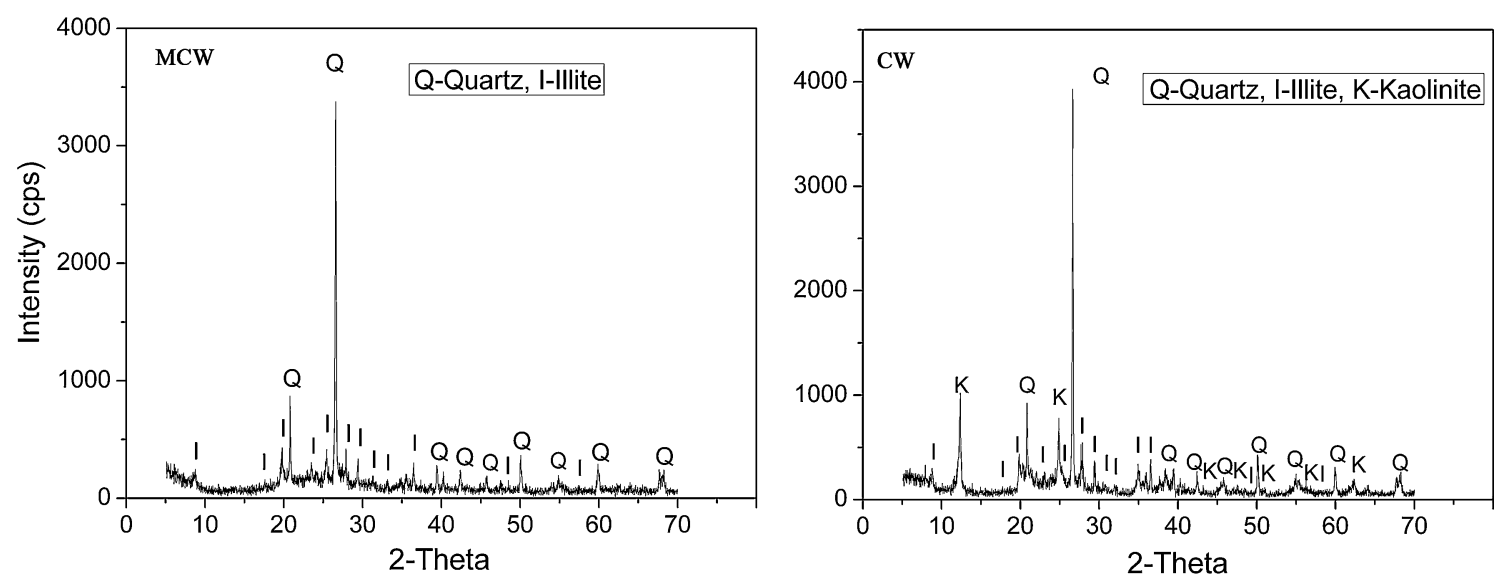

Fig. 2 X-ray diffraction pattern of $\mathrm{CW}$ and $\mathrm{MCW}$

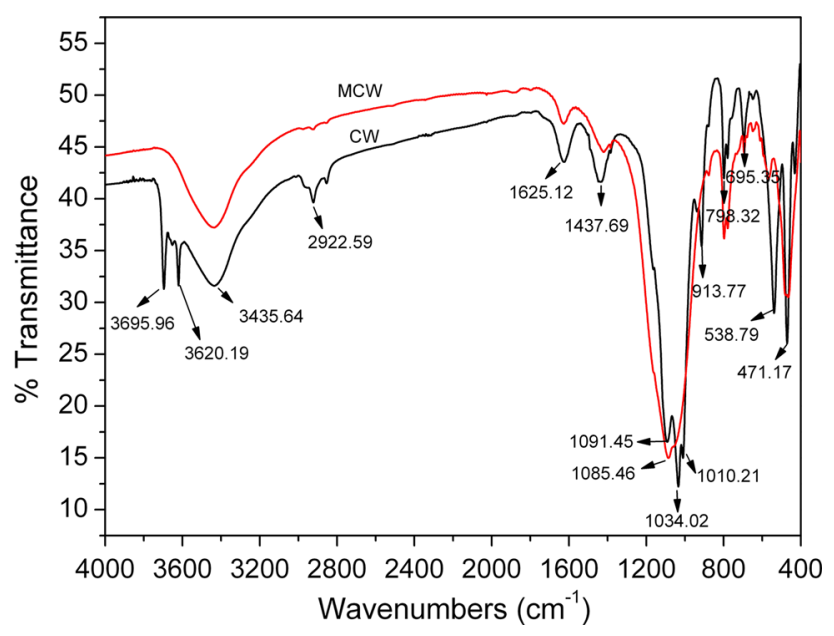

Fig. 3 FTIR spectrum of $\mathrm{CW}$ and $\mathrm{MCW}$

(Saikia and Parthasarathy 2010). The bands at 695.35 and $798.32 \mathrm{~cm}^{-1}$ could be assigned to symmetry vibration of $\mathrm{Si}-\mathrm{O}-\mathrm{Si}$. For $\mathrm{MCW}$, Stretching vibrations of $\mathrm{OH}-$ at $3,695.96$ and $3,620.19 \mathrm{~cm}^{-1}$ disappear due to dehydroxylation of kaolinite by calcination treatment at $700{ }^{\circ} \mathrm{C}$, which indicates that crystal structure of kaolinite were decomposed (Kakali et al. 2001). Absence of the detectable characteristic bands of kaolinite, $\mathrm{Al}-\mathrm{O}-\mathrm{H}$ bands at $913.77 \mathrm{~cm}^{-1}$, Si-O bands at 1,010.21, $1,034.02$ and $1,091.45 \mathrm{~cm}^{-1}$ and $\mathrm{Si}-\mathrm{O}-\mathrm{Al}^{\mathrm{VI}}$ at $538.79 \mathrm{~cm}^{-1}$, and the appearance of a new band at $568.30 \mathrm{~cm}^{-1}$ (Al-O stretching) can be caused by the change from octahedral coordination of $\mathrm{Al}^{3+}$ in kaolinite to tetrahedral coordination in metakaolinite (Kakali et al. 2001). Stretching vibrations of $\mathrm{Si}-\mathrm{O}$ at $1,085.46 \mathrm{~cm}^{-1}$ and bending vibrations of $\mathrm{Si}-\mathrm{O}$ at $466.76 \mathrm{~cm}^{-1}$ appeared in the shape of broadband, which are the characteristic absorption bands of metakaolinite (Kakali et al. 2001; Saikia and Parthasarathy 2010). It is also indicated from FTIR spectra that silanol and aluminol groups are abundant in the adsorbents.

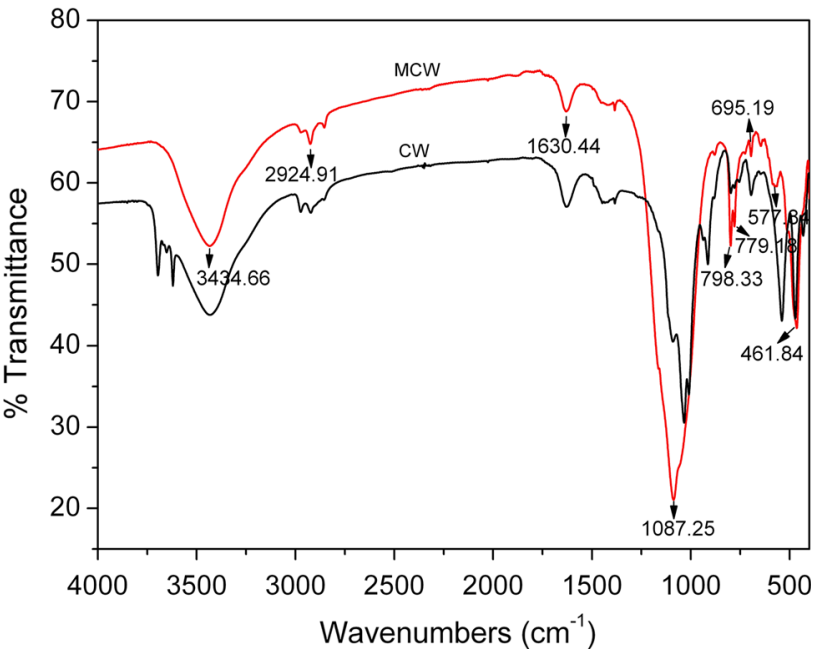

Fig. 4 FTIR spectra for Cd(II)-loaded MCW and CW

The FTIR spectra for Cd(II)-loaded adsorbents was presented in Fig. 4. It shows that the wavenumbers shifted from 568.30 to $577.84 \mathrm{~cm}^{-1}$ (Al-O), 466.76 to $461.84 \mathrm{~cm}^{-1}$ ( $\mathrm{Si}-$ $\mathrm{O}$ ) and $1,085.46$ to $1,087.25 \mathrm{~cm}^{-1}(\mathrm{Si}-\mathrm{O})$, respectively, after $\mathrm{Cd}(\mathrm{II})$ adsorption onto $\mathrm{MCW}$. It proved that silanol and aluminol groups were primary contributors involved in the adsorption of $\mathrm{Cd}(\mathrm{II})$ onto $\mathrm{MCW}$. While, the functional groups did not shift the peak significantly for $\mathrm{CW}$, only the intensity change of the bands in FTIR spectra after binding with $\mathrm{Cd}(\mathrm{II})$ was observed, maybe due to the low adsorption capacity. EDS spectra for MCW and CW after the adsorption of Cd(II) are shown in Fig. 5. EDS spectra (figures not presented) for the raw adsorbents did not show the characteristic signal of $\mathrm{Cd}(\mathrm{II})$, while the presence of $\mathrm{Cd}(\mathrm{II})$ was observed for the adsorbents after adsorption.

\section{Effect of $\mathrm{pH}$}

The adsorption efficiency for $\mathrm{Cd}(\mathrm{II})$ increased with increasing $\mathrm{pH}$ as expected, and the equilibrium was 


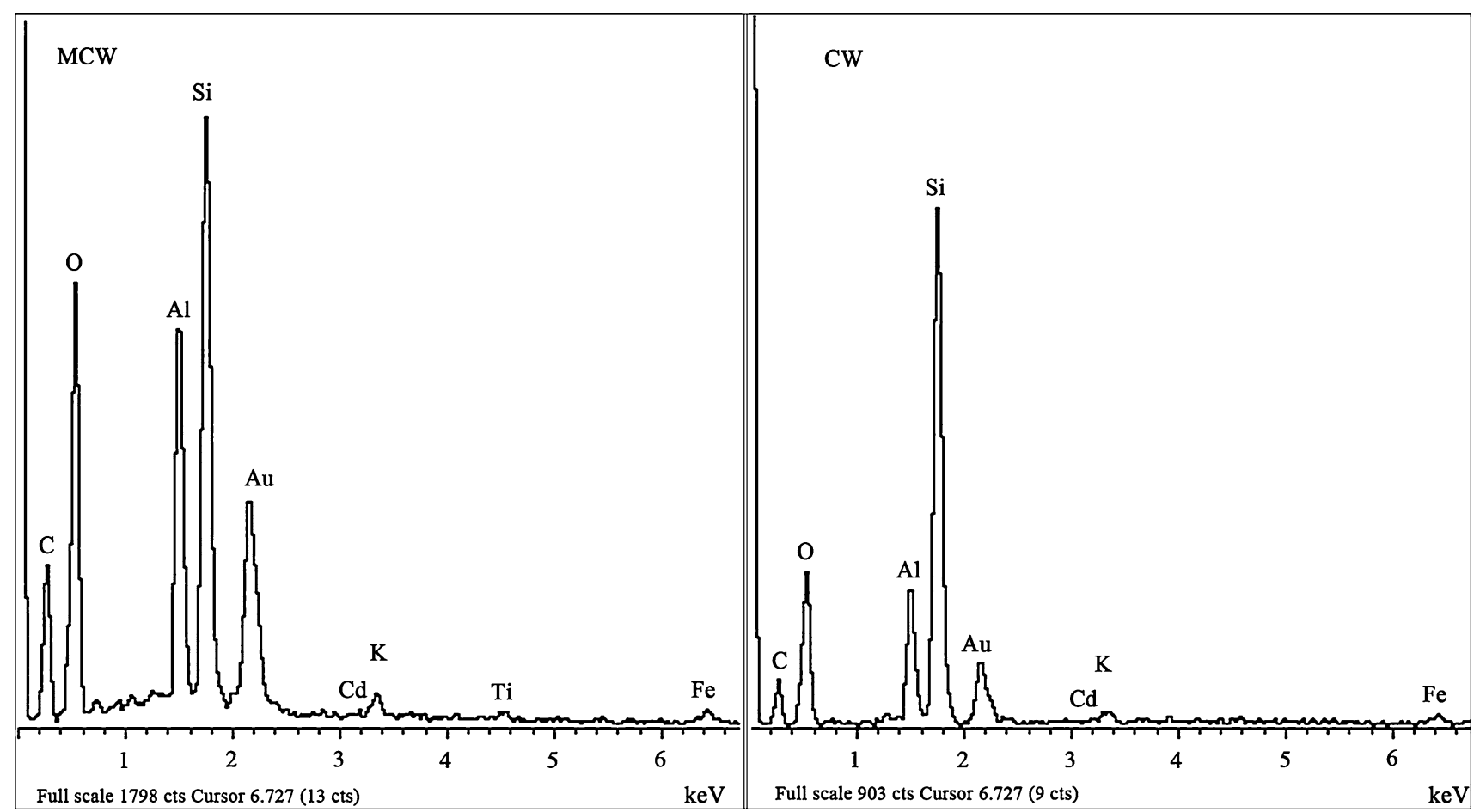

Fig. 5 Energy dispersion spectrometer spectra of $\mathrm{MCW}$ and $\mathrm{CW}$ after $\mathrm{Cd}(\mathrm{II})$ adsorption

achieved above $\mathrm{pH}_{\mathrm{pzc}}$ (Fig. 6). With $\mathrm{pH}$ increasing, the lower number of $\mathrm{H}^{+}$and greater number of negatives charges distributed on the adsorbent surface can result in greater $\mathrm{Cd}(\mathrm{II})$ adsorption through electrostatic force of attraction. The optimum $\mathrm{pH}$ value for adsorption of $\mathrm{Cd}(\mathrm{II})$ by the $\mathrm{CW}$ and MCW adsorbents was found to be 6.5 and 6.0 , respectively, at which the removal efficiency of $\mathrm{Cd}(\mathrm{II})$ was observed to be 28.57 and $94.48 \%$. Therefore, all the following experiments on adsorption of $\mathrm{Cd}(\mathrm{II})$ were

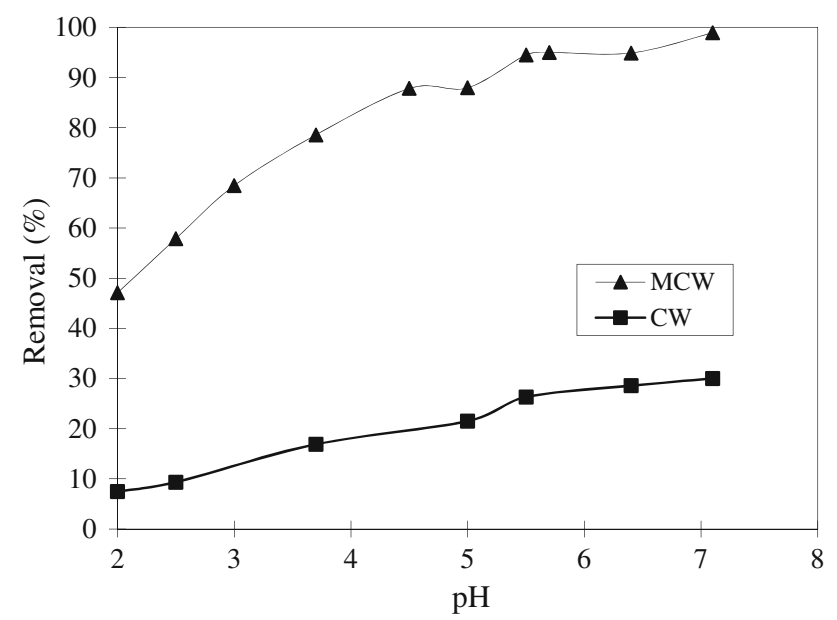

Fig. 6 Effect of pH on adsorption of Cd(II). Experimental conditions: adsorbent dosage $15 \mathrm{~g} \mathrm{~L}^{-1}$, contact time $120 \mathrm{~min}$, initial concentration $0.2 \mathrm{mmol} \mathrm{L}^{-1}$ and $\mathrm{T} 298 \mathrm{~K}$ conducted by maintaining the solution at $\mathrm{pH} 6.0$ for $\mathrm{MCW}$ and 6.5 for $\mathrm{CW}$.

The main functional groups of the adsorbents, silanol and aluminol groups, may be responsible for the $\mathrm{Cd}(\mathrm{II})$ adsorption on $\mathrm{CW}$ and $\mathrm{MCW}$. The silanol groups are negatively charged at low $\mathrm{pH}$ range $(\mathrm{pH} 2-3$; near the $\mathrm{pH}_{\mathrm{PZC}}$ value of silanol), which facilitate the adsorption of $\mathrm{Cd}$ (II) in this $\mathrm{pH}$ range (Gundogdu et al.2009; Shi et al. 2009). As a result, adsorption can occur even at low $\mathrm{pH}$. Aluminol groups are negatively charged at $\mathrm{pH}$ around 6, which further favor the adsorption of $\mathrm{Cd}(\mathrm{II})$ on the surface of the adsorbents. The adsorption behavior for $\mathrm{Cd}(\mathrm{II})$ can be expressed in Eqs. (3) and (4) (silanol for example):

$\equiv \mathrm{Si}-\mathrm{OH}+\mathrm{Cd}^{2+} \Leftrightarrow \equiv \mathrm{Si}-\mathrm{OCd}^{+}+\mathrm{H}^{+}$

$\equiv \mathrm{Si}-\mathrm{O}^{-}+\mathrm{Cd}^{2+} \Leftrightarrow \equiv \mathrm{Si}-\mathrm{OCd}^{+}$

Effect of the initial concentration

The effect of initial $\mathrm{Cd}(\mathrm{II})$ concentration on the adsorption efficiency was investigated in the range of $0.05-1.5 \mathrm{mmol} \mathrm{L}^{-1}$ at 298,308 and $318 \mathrm{~K}$. The results show that the adsorption efficiency decreased with increasing initial $\mathrm{Cd}$ (II) concentration. The lower adsorption efficiency at higher concentration resulted from an increasing ratio of initial number of moles of $\mathrm{Cd}$ (II) to the available adsorption sites. The available adsorption site was fixed per mass of adsorbent dose. Accordingly, it resulted in a decrease in the removal efficiency of metal 


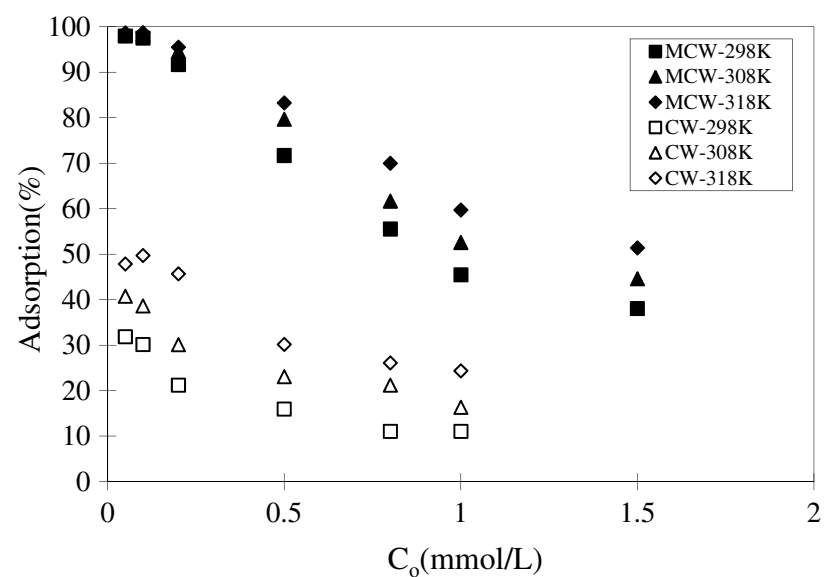

Fig. 7 Effect of initial ion concentration on adsorption of $\mathrm{Cd}(\mathrm{II})$. Experimental conditions: $\mathrm{pH} 6.0$ for $\mathrm{MCW}$ and 6.5 for $\mathrm{CW}$, adsorbent dosage $15 \mathrm{~g} \mathrm{~L}^{-1}$, contact time $120 \mathrm{~min}$ and $\mathrm{T} 298 \mathrm{~K}$

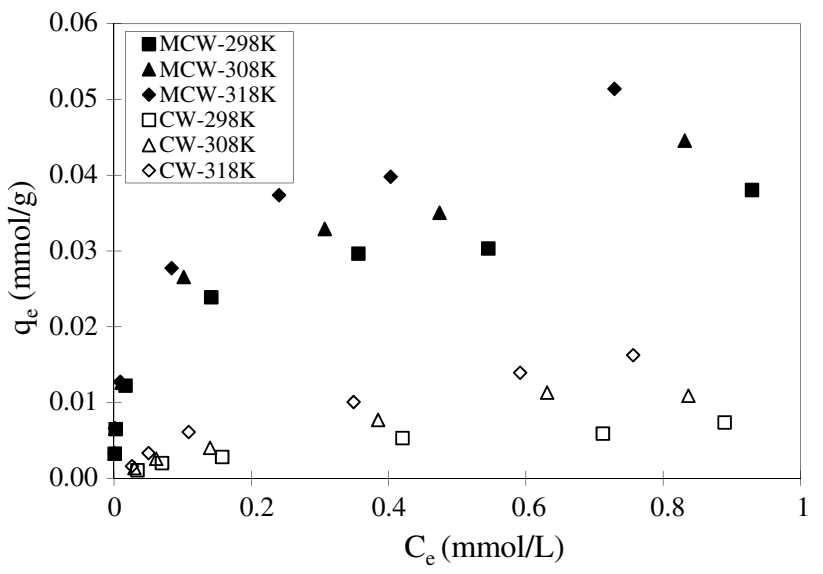

Fig. 8 The adsorption isotherms for adsorption of $\mathrm{Cd}(\mathrm{II})$ on $\mathrm{MCW}$ and $\mathrm{CW}$ at 298, 308 and $318 \mathrm{~K}$. Experimental conditions: pH 6.0 for $\mathrm{MCW}$ and 6.5 for $\mathrm{CW}$, adsorbent dosage $15 \mathrm{~g} \mathrm{~L}^{-1}$ and contact time $120 \mathrm{~min}$

ion, with increase in initial metal ion concentration (saturation of the adsorbent). It is also observed that the adsorption efficiencies of $\mathrm{Cd}(\mathrm{II})$ onto $\mathrm{CW}$ and $\mathrm{MCW}$ increased with temperature increasing from 298 to $318 \mathrm{~K}$ (Fig. 7). For example, at the initial concentration of $0.5 \mathrm{mmol} \mathrm{L}^{-1}$, the adsorption efficiencies of $\mathrm{Cd}(\mathrm{II})$ onto CW and MCW increased from 71.68 to $83.24 \%$ and from 23.09 to $30.20 \%$, respectively, with temperature increasing from 298 to $318 \mathrm{~K}$.

\section{Effect of adsorbent dosage}

It is observed that with the adsorbent dosage increasing from 5 to $50 \mathrm{~g} \mathrm{~L}^{-1}$, the adsorption efficiency of $\mathrm{Cd}$ (II) increased, while the adsorption capacity decreased. Because of the higher adsorbent dosage in the solution, more available adsorption sites are available and more
Cd(II) were adsorbed. The decrease in adsorption capacity of $\mathrm{Cd}(\mathrm{II})$ with the adsorbent dosage increasing is due to the existence of unsaturated adsorption sites (Ho and Mckay 1998; Manohar et al. 2002). It is also observed that the adsorption efficiency of $\mathrm{Cd}(\mathrm{II})$ was not increased significantly when the adsorbent dosage is higher than $15 \mathrm{~g} \mathrm{~L}^{-1}$, which was chosen as the optimum adsorbent dosage. The active adsorption sites on the adsorbent surface are then occupied and further increase in the adsorbent dosage cannot bring higher adsorption efficiency.

\section{Effect of particle size}

The results show that adsorption efficiency of $\mathrm{Cd}(\mathrm{II})$ increased from 86.86 to $95.54 \%$ and from 18.34 to $37.61 \%$ for $\mathrm{MCW}$ and $\mathrm{CW}$, as the particle size of the adsorbents decreased from 40 to 60 mesh to 80 to 100 mesh. With the particle size decreasing, the surface area of adsorbent will increase and more adsorption sites are available for $\mathrm{Cd}(\mathrm{II})$ to be adsorbed. Hence, adsorption efficiency will be enhanced. However, when particle size decreased to a sufficient extent (smaller than 100 mesh), the adsorption efficiency increased $<2 \%$, and it had no significant influence on $\mathrm{Cd}(\mathrm{II})$ adsorption.

\section{Adsorption isotherms}

The Langmuir and Freundlich models were used to simulate adsorption isotherms. The linear forms of the Langmuir and Freundlich isotherms are presented by Eqs. (5) and (6).

$\frac{C_{\mathrm{e}}}{q_{\mathrm{e}}}=\frac{1}{b q_{\max }}+\frac{C_{\mathrm{e}}}{q_{\max }}$

$\log q_{\mathrm{e}}=\log K_{\mathrm{F}}+\frac{1}{n} \log C_{\mathrm{e}}$

Where $q_{\mathrm{e}}$ is the amount adsorbed per mass of adsorbent at equilibrium $\left(\mathrm{mmol} \mathrm{g}^{-1}\right), C_{\mathrm{e}}$ is the concentration of

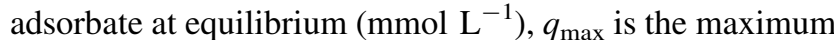
adsorption capacity $\left(\mathrm{mmol} \mathrm{g}^{-1}\right)$ and $b\left(\mathrm{~L} \mathrm{~mol}^{-1}\right)$ is the adsorption equilibrium constant related to adsorption energy. $\quad K_{\mathrm{F}}\left(\mathrm{mmol} \mathrm{g}^{-1}\right)$ and $1 / n$ (unitless) are the Freundlich constants related to adsorption capacity and intensity, respectively.

The essential feature of the Langmuir model can be described by using a separation factor $\left(R_{\mathrm{L}}\right)$, which is defined by Eq. (7).

$R_{\mathrm{L}}=\frac{1}{1+b C_{\mathrm{o}}}$

Where $R_{\mathrm{L}}$ values indicate the type of isotherm as being favorable adsorption $\left(0<R_{\mathrm{L}}<1\right)$, unfavorable adsorption $\left(R_{\mathrm{L}}>1\right)$, linear adsorption $\left(R_{\mathrm{L}}=1\right)$ or irreversible adsorption $\left(R_{\mathrm{L}}=0\right)$. 
Table 1 Parameters of the Langmuir and Freundlich isotherm models of Cd(II) adsorption at 298, 308 and $318 \mathrm{~K}$

\begin{tabular}{|c|c|c|c|c|c|c|c|c|}
\hline \multirow[t]{2}{*}{ Adsorbent } & \multirow[t]{2}{*}{$T(\mathrm{~K})$} & \multirow{2}{*}{$\begin{array}{l}\text { Langmuir } \\
q_{\max }\left(\mathrm{mmol} \mathrm{g}^{-1}\right)\end{array}$} & \multicolumn{6}{|l|}{ Freundlich } \\
\hline & & & $\mathrm{b}\left(\mathrm{L} \mathrm{mol}^{-1}\right)$ & $R^{2}$ & $R_{\mathrm{L}}$ & $K_{F}\left(\mathrm{mmol} \mathrm{g}^{-1}\right)$ & $n$ & $R^{2}$ \\
\hline \multirow[t]{3}{*}{ MCW } & 298 & 0.037 & 21.016 & 0.98 & $0.03-0.49$ & 0.041 & 2.991 & 0.97 \\
\hline & 308 & 0.044 & 23.051 & 0.97 & $0.03-0.46$ & 0.051 & 2.908 & 0.96 \\
\hline & 318 & 0.051 & 23.556 & 0.97 & $0.03-0.46$ & 0.061 & 2.757 & 0.98 \\
\hline \multirow[t]{3}{*}{$\mathrm{CW}$} & 298 & 0.009 & 3.46 & 0.97 & $0.22-0.85$ & 0.008 & 1.783 & 0.97 \\
\hline & 308 & 0.016 & 2.842 & 0.95 & $0.26-0.88$ & 0.014 & 1.578 & 0.98 \\
\hline & 318 & 0.022 & 3.112 & 0.97 & $0.24-0.87$ & 0.02 & 1.553 & 0.96 \\
\hline
\end{tabular}

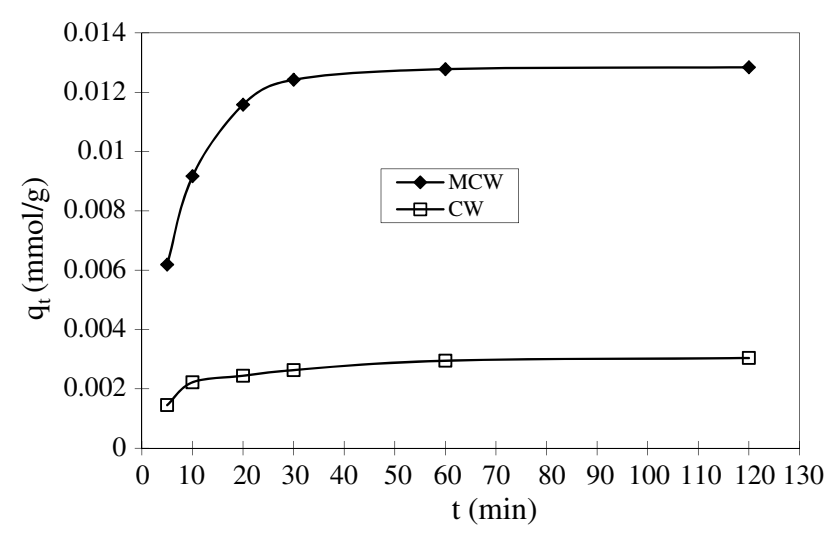

Fig. 9 The adsorption kinetic for adsorption of $\mathrm{Cd}(\mathrm{II})$. Experimental conditions: $\mathrm{pH} 6.0$ for MCW and 6.5 for $\mathrm{CW}$, adsorbent dosage $15 \mathrm{~g} / \mathrm{l}$, contact time $120 \mathrm{~min}$, initial concentration $0.2 \mathrm{mmol} / \mathrm{L}$ and T $298 \mathrm{~K}$

The plots of the adsorption isotherm of $\mathrm{Cd}(\mathrm{II})$ on $\mathrm{CW}$ and MCW at different temperatures $(298,308$ and $318 \mathrm{~K})$ are shown in Fig. 8. The parameters for Langmuir and Freundlich isotherm models are listed in Table 1. It shows that the Langmuir and Freundlich models fit well for the adsorption of $\mathrm{Cd}(\mathrm{II})$ on the two adsorbents with the high values of $R^{2}(0.95-0.98)$. The maximum adsorption capacity $\left(q_{\max }\right)$ increased from 0.037 to $0.051 \mathrm{mmol} \mathrm{g}^{-1}(\mathrm{MCW})$ and from 0.009 to $0.022 \mathrm{mmol} \mathrm{g}^{-1}$ (CW) with temperature increasing from 298 to $318 \mathrm{~K}$. This suggested that the adsorption of $\mathrm{Cd}(\mathrm{II})$ onto the two adsorbents was endothermic in nature, which is proved by adsorption thermodynamic parameters described below. It was also obvious that the $q_{\max }$ of $\mathrm{Cd}$ (II) on MCW was larger than that of CW, as calcination treatment increased the adsorption capacity. However, the adsorption capacities of $\mathrm{CW}$ and MCW are lower, compared with some other adsorbents in literature (Ajmal et al. 2003; Naiya et al. 2009).

The Langmiur constant, $b$, related to adsorption energy indicates the strength and affinity of the adsorbents for the solute. For the adsorption of $\mathrm{Cd}(\mathrm{II})$ on $\mathrm{MCW}$, it was about seven times larger than for $\mathrm{CW}$ and it increased with increasing temperature, while for $\mathrm{CW}$ adsorbent, the Langmiur constant, $b$, decreased with increasing temperature. This indicated that
$\mathrm{Cd}$ (II) had higher affinity toward the surface of MCW than CW and the adsorption process may be more stable on MCW than on CW. All the values of $R_{\mathrm{L}}$ were in the range of $0.03-0.49$ for $\mathrm{MCW}$ and $0.22-0.87$ for $\mathrm{CW}$ for the initial Cd(II) concentration range of 0.05 to $1.5 \mathrm{mmol} \mathrm{L}^{-1}$, indicating favorable adsorption of $\mathrm{Cd}(\mathrm{II})$ onto the two adsorbents.

As expected, the values of Freundlich constant $K_{\mathrm{F}}$ for the adsorption on MCW were greater than that of adsorption on $\mathrm{CW}$, and the value of $K_{\mathrm{F}}$ all increased with temperature increasing from 298 to $318 \mathrm{~K}$. The values of $n$ between 1 and 10 (i.e., $1 / n<1$ ) represent a favorable adsorption (Naiya et al. 2009).

\section{Kinetics}

Kinetic analysis was conducted by pseudo-first-order and pseudo-second-order models. The linear forms of the kinetic models are given in Eqs. (8) and (9)

$\log \left(q_{\mathrm{e}}-q_{\mathrm{t}}\right)=\log q_{\mathrm{e}}-\frac{k_{1} t}{2.303}$

$\frac{t}{q_{t}}=\frac{1}{k_{2} q_{e}^{2}}+\frac{1}{q_{e}} t$

Where $q_{t}$ is the amount of Cd(II) adsorbed by MCW or $\mathrm{CW}$ at time $t\left(\mathrm{mmol} \mathrm{g}^{-1}\right)$, and $k_{1}\left(\mathrm{~min}^{-1}\right), k_{2}\left(\mathrm{~g} \mathrm{mmol} \mathrm{min}^{-1}\right)$ are the rate constants of the pseudo-first-order model and pseudo-second-order model, respectively; $t$ is the adsorption time (min).

The adsorption of $\mathrm{Cd}(\mathrm{II})$ on the two adsorbents showed typical biphasic kinetics with rapid adsorption in the first $10 \mathrm{~min}$, and then, the adsorption capacity slowly reached equilibrium. This is because initially abundant active sites are available for adsorption and $\mathrm{Cd}(\mathrm{II})$ concentration gradient is high. Afterward, few surface active sites become available and difficult to be occupied due to repulsive forces between the solute molecules of the solid and bulk phase; therefore, very slow increase in the $\mathrm{Cd}$ (II) adsorption is observed. Adsorption equilibrium was achieved within $120 \mathrm{~min}$ for $\mathrm{Cd}(\mathrm{II})$ adsorption onto the two adsorbents. Thus, 120 min of contact time was considered as the optimum time in each adsorption experiment. 
Table 2 Theoretically determined parameters of pseudo-first order and pseudo-second order

\begin{tabular}{|c|c|c|c|c|c|c|c|}
\hline \multirow[t]{2}{*}{ Adsorbent } & \multirow[t]{2}{*}{ Experimental $q_{\mathrm{e}}\left(\mathrm{mmol} \mathrm{g}^{-1}\right)$} & \multicolumn{3}{|c|}{ Pseudo-first order } & \multicolumn{3}{|c|}{ Pseudo-second order } \\
\hline & & $q_{\mathrm{e}}\left(\mathrm{mmol} \mathrm{g}^{-1}\right)$ & $k_{1}\left(\min ^{-1}\right)$ & $R^{2}$ & $q_{\mathrm{e}}\left(\mathrm{mmol} \mathrm{g}^{-1}\right)$ & $k_{2}\left(\mathrm{~g} \mathrm{mmol} \cdot \mathrm{min}^{-1}\right)$ & $R^{2}$ \\
\hline MCW & 0.012 & 0.004 & 0.127 & 0.93 & 0.013 & 19.304 & 0.99 \\
\hline CW & 0.003 & 0.001 & 0.062 & 0.92 & 0.003 & 57.184 & 0.99 \\
\hline
\end{tabular}

Table 3 Thermodynamic parameters of Cd(II) adsorption on MCW and $\mathrm{CW}$ at 298,313 and $318 \mathrm{~K}$

\begin{tabular}{|c|c|c|c|c|}
\hline Adsorbent & $\begin{array}{l}\text { Temperature } \\
(\mathrm{K})\end{array}$ & $\begin{array}{l}\Delta \mathrm{G}^{0} \\
\left(\mathrm{~kJ} \mathrm{~mol}^{-1}\right)\end{array}$ & $\begin{array}{l}\Delta \mathrm{H}^{\mathrm{o}} \\
\left(\mathrm{kJ} \mathrm{mol}^{-1}\right)\end{array}$ & $\begin{array}{l}\Delta \mathrm{S}^{\mathrm{o}}\left(\mathrm{J} \mathrm{mol}^{-1}\right. \\
\left.\mathrm{K}^{-1}\right)\end{array}$ \\
\hline \multirow[t]{3}{*}{$\mathrm{MCW}$} & 298 & -17.24 & \multirow[t]{3}{*}{19.75} & \multirow[t]{3}{*}{124.12} \\
\hline & 308 & -18.65 & & \\
\hline & 318 & -19.73 & & \\
\hline \multirow[t]{3}{*}{$\mathrm{CW}$} & 298 & -8.3 & \multirow[t]{3}{*}{32.23} & \multirow[t]{3}{*}{135.83} \\
\hline & 308 & -9.58 & & \\
\hline & 318 & -11.03 & & \\
\hline
\end{tabular}

The adsorption kinetic for adsorption of $\mathrm{Cd}(\mathrm{II})$ is shown in Fig. 9. The kinetic parameters of $\mathrm{Cd}(\mathrm{II})$ adsorption on $\mathrm{CW}$ and MCW are presented in Table 2. As shown, the theoretical $q_{\mathrm{e}}$ values calculated from pseudo-first order had significant difference compared to experimental values, and the correlation coefficients $\left(R^{2}\right)$ were very low, while the pseudo-second-order model described the experimental data well, evidenced by correlation coefficients $\left(\mathrm{R}^{2}\right)$ close to 1 and the theoretical $q_{\mathrm{e}}$ values of $\mathrm{Cd}(\mathrm{II})$ almost equal to the experimental $q_{\mathrm{e}}$ values. This indicates that the rate-limiting step may be the chemical adsorption (Ding et al. 2006).

\section{Thermodynamic parameters}

In the thermodynamic study, the thermodynamic parameters, that is, the Gibbs free energy $\left(\Delta \mathrm{G}^{0}\right)$, enthalpy $\left(\Delta \mathrm{H}^{0}\right)$ and entropy $\left(\Delta S^{0}\right)$ changes, were determined by using the following equations (Yang et al. 2011; Zhao et al. 2011a, b):

$\Delta \mathrm{G}^{\mathrm{o}}=-R T \ln \mathrm{K}^{\mathrm{o}}$

where $R$ is the ideal gas constant $\left(8.314 \mathrm{~J} \mathrm{~mol} \cdot \mathrm{K}^{-1}\right) ; T$ is the Kelvin temperature; $\mathrm{K}^{\mathrm{o}}$, the adsorption equilibrium constant, is obtained by plotting $\ln \mathrm{K}_{\mathrm{d}}$ versus $C_{\mathrm{e}}$ and extrapolating $C_{\mathrm{e}}$ to zero. The intercept value is that of $\ln$ $\mathrm{K}^{\mathrm{o}}$. The distribution adsorption coefficient, $\mathrm{K}_{\mathrm{d}}$, can be determined from Eq. (11) (Zhao et al. 2011a, b):

$K_{d}=\frac{C_{\mathrm{o}}-C_{\mathrm{e}}}{C_{\mathrm{e}}} \cdot \frac{V}{m}$

The enthalpy change $\left(\Delta H^{0}\right)$ and entropy change $\left(\Delta S^{0}\right)$ can be calculated from the slope and intercept of the plot of ln $\mathrm{K}^{\mathrm{o}}$ versus $1 / T$ by Eq. (12). $\ln \mathrm{K}^{0}=\frac{\Delta \mathrm{S}^{0}}{R}-\frac{\Delta \mathrm{H}^{0}}{R T}$

The thermodynamic parameters were calculated from the adsorption isotherms of $\mathrm{Cd}(\mathrm{II})$ on $\mathrm{CW}$ and $\mathrm{MCW}$ at different temperatures. According to $\operatorname{Eq}(12)$, the slope and intercept of the plot of $\ln \mathrm{K}^{\mathrm{o}}$ versus $1 / T$ were calculated, respectively.

Thermodynamic parameters of $\mathrm{Cd}(\mathrm{II})$ adsorption on $\mathrm{CW}$ and MCW calculated from Eqs. (10)-(12) were presented in Table 3. The negative Gibbs free energy change $\left(\Delta G^{0}\right)$ indicates that the adsorption process is spontaneous. The values of $\Delta \mathrm{G}^{0}$ decreased with the temperature increasing from 298 to $318 \mathrm{~K}$, which indicates the endothermic adsorptions of $\mathrm{Cd}(\mathrm{II})$ onto $\mathrm{CW}$ and $\mathrm{MCW}$ were enhanced with increasing temperature. The enthalpy of the adsorption, $\Delta \mathrm{H}^{0}$, is a indication of the energy barrier that must be overcome during the adsorption process by reacting molecules (Unuabonah et al. 2008). The positive $\Delta \mathrm{H}^{0}$ suggests that the adsorption reaction onto the two adsorbents are endothermic in nature, which shows that increasing temperature will promote the adsorption of $\mathrm{Cd}(\mathrm{II})$ onto the adsorbents. This is an indication of chemical reaction or bonding process being involved in $\mathrm{Cd}(\mathrm{II})$ adsorption process; thus, the adsorption processes may belong to chemical sorption. The value of $\Delta \mathrm{S}^{0}$ can determine whether the adsorption process is associative or dissociative mechanism. Generally, entropy change $\Delta \mathrm{S}^{0}>-10^{-2} \mathrm{~kJ} \mathrm{Kmol}^{-1}$ indicates dissociative mechanism (Scheckel and Sparks 2001; Shi et al. 2009; Zhao et al. 2011a, b). The values of $\Delta \mathrm{S}^{0}$ of $\mathrm{Cd}(\mathrm{II})$ adsorption on the two adsorbents were all positive, which indicated that dissociative mechanism could be involved in the adsorption processes (Shi et al. 2009; Zhao et al. 2011a, b).

\section{Desorption}

The desorption results are shown in Table 4, which showed that the two adsorbents could be used repeatedly at least three times without significant decrease in the adsorption capacity for $\mathrm{Cd}(\mathrm{II})$. It is also observed that $\mathrm{Cd}(\mathrm{II})$ desorption for MCW was generally smaller than that of $\mathrm{CW}$, which suggests that the MCW bind $\mathrm{Cd}(\mathrm{II})$ ion more strongly than $\mathrm{CW}$. This strongly correlated with the earlier suggestion from the binding energy constant $(b)$. 
Table 4 Adsorption and desorption amount of Cd(II) by CW and MCW in adsorption-desorption cycles

\begin{tabular}{lllllll}
\hline Adsorbent & $\begin{array}{l}\text { Cycle } \\
\text { no. }\end{array}$ & $\begin{array}{l}\text { Amount before adsorption } \\
\left(\mathrm{mmol} \mathrm{L}^{-1}\right)\end{array}$ & $\begin{array}{l}\text { Amount after adsorption } \\
(\mathrm{mmol} \mathrm{L})\end{array}$ & $\begin{array}{l}\text { Adsorption } \\
(\%)\end{array}$ & $\begin{array}{l}\text { Amount desorbed with } 0.1 \mathrm{~mol} \mathrm{~L} \\
\mathrm{HCl}(\mathrm{mmol} \mathrm{L})\end{array}$ & $\begin{array}{l}\text { Recovery } \\
(\%)\end{array}$ \\
\hline MCW & 1 & 0.5 & 0.132 & 73.6 & 0.339 & 92.12 \\
& 2 & 0.5 & 0.141 & 71.8 & 0.321 & 89.42 \\
& 3 & 0.5 & 0.136 & 72.8 & 0.316 & 96.81 \\
$\mathrm{CW}$ & 1 & 0.5 & 0.416 & 16.8 & 0.081 & 96.43 \\
& 2 & 0.5 & 0.422 & 15.6 & 0.072 & 90.31 \\
& 3 & 0.5 & 0.435 & 13 & 0.059 & 90.77 \\
\hline
\end{tabular}

\section{Conclusion}

Calcination treatment can impart loose structure and higher specific surface area to coal waste, enabling calcinationtreated $\mathrm{CW}$ to have a higher adsorption capacity for $\mathrm{Cd}(\mathrm{II})$. The adsorption of $\mathrm{Cd}(\mathrm{II})$ on the adsorbents increased with increasing temperature from 298 to $318 \mathrm{~K}$. The adsorption efficiency for $\mathrm{Cd}$ (II) increased with increasing $\mathrm{pH}$, and the optimum $\mathrm{pH}$ value for adsorption of $\mathrm{Cd}$ (II) by the $\mathrm{CW}$ and MCW adsorbents was found to be 6.5 and 6.0, respectively. It is observed that the adsorption efficiency of $\mathrm{Cd}$ (II) was not increased significantly when adsorbent dosage was higher than $15 \mathrm{~g} \mathrm{~L}^{-1}$, which was considered as an optimum adsorbent dosage level at the specified conditions. The equilibrium of the adsorption can be reached within $120 \mathrm{~min}$, and the process can be simulated by pseudosecond-order model. Thermodynamic analysis showed the adsorption processes were endothermic and spontaneous processes, and they may be chemical in nature with positive $\Delta \mathrm{H}^{0}$; the positive $\Delta \mathrm{S}^{0}$ suggests that dissociative processes were involved in the adsorption of $\mathrm{Cd}(\mathrm{II})$. The desorption results indicated that the two adsorbents could be used repeatedly (at least three times) without significant decrease in the adsorption capacity for $\mathrm{Cd}(\mathrm{II})$. The FTIR studies indicated that silanol and aluminol were primary functional groups responsible for metal binding.

Acknowledgments This work was supported by Shandong Provincial Natural Science Foundation, China (ZR2010DQ005, ZR2010DL005), the Natural Science Foundation of China (41172222) and Doctoral Foundation of University Jinan (XBS1036).

\section{References}

Ajmal M, Khan AH, Ahmad S, Ahmad A (1998) Role of sawdust in the removal of copper (II) from industrial wastes. Water Res 22:3085-3091

Ajmal M, Rao R, Anwar JA, Ahmad R (2003) Adsorption studies on rice husk: removaland recovery of $\mathrm{Cd}$ (II) from wastewater. Bioresour Technol 86:147-149

Amuda OS, Giwa AA, Bello IA (2007) Removal of heavy metal from industrial wastewater using modified activated coconut shell carbon. Biochem Eng J 36:174-181
Aydin H, Bulut Y, Yerlikaya C (2008) Removal of copper (II) from aqueous solution by adsorption onto low-cost adsorbents. J Environ Manage 87:37-45

Dias JM, Alvim-Ferraz MCM, Almeida MF, Rivera-Utrilla J, Sanchez-Polo M (2007) Waste materials for activated carbon preparation and its use in aqueous phase treatment: a review. J Environ Manage 85:833-846

Ding P, Huang K, Li G, Liu Y, Zeng W (2006) Kinetics of adsorption of $\mathrm{Zn}(\mathrm{II})$ ion on chitosan derivatives. Int $\mathrm{J}$ Biol Macromol 39:222-227

Gundogdu A, Ozdes D, Duran C, Bulut VN, Soylak M (2009) Biosorption of $\mathrm{Pb}(\mathrm{II})$ ions from aqueous solution by pine bark (Pinus brutia Ten.). Chem Eng J 153:62-69

Gupta VK, Ali I (2004) Removal of lead and chromium from wastewater using bagasse fly ash-a sugar industry waste. J Colloid Interface Sci 271:321-328

Ho YS, McKay G (1998) Kinetic models for the sorption of dye from aqueous solution by wood. J Environ Sci Health Part B Process Saf Environ Prot 76:183-191

Kakali G, Perraki T, Tsivilis S, Badogiannis E (2001) Thermal treatment of kaolin: the effect of mineralogy on the pozzolanic activity. Appl Clay Sci 20:73-80

Kuang J, Qiu T, Shi F (2012) Effect of heat treatment on structure transformation and activities of kaolinite. Chin $\mathrm{J}$ Nonferrous Metals 22:258-264

Manohar DM, Krishnan KA, Anirudhan TS (2002) Removal of mercury(II) from aqueous solutions and chlor-alkali industry wastewater using 2-mercaptobenzimidazole-clay. Water Res 36:1609-1619

Munagapati VS, Yarramuthi V, Nadavala SK, Alla SR, Abburi K (2010) Biosorption of $\mathrm{Cu}(\mathrm{II}), \mathrm{Cd}(\mathrm{II})$ and $\mathrm{Pb}(\mathrm{II})$ by Acacia leucocephala bark powder: kinetics, equilibrium and thermodynamics. Chem Eng J 157:357-365

Naiya TK, Bhattacharya AK, Mandal S, Das SK (2009) The sorption of lead(II) ions on rice husk ash. J Hazar Mater 163:1254-1264

Pehlivan E, Altun T, Cetin S, Bhanger MI (2009) Lead sorption by waste biomass of hazelnut and almond shell. J Hazard Mater 167:1203-1208

Qin F, Wen B, Shan XQ, Xie YN, Liu T, Zhang SZ, Khan SU (2006) Mechanisms of competitive adsorption of $\mathrm{Pb}, \mathrm{Cu}$, and $\mathrm{Cd}$ on peat. Environ Pollut 144:669-680

Saikia BJ, Parthasarathy G (2010) Fourier Transform Infrared Spectroscopic Characterization of Kaolinite from Assam and Meghalaya, Northeastern India. J Mod Phys 1:206-210

Scheckel KG, Sparks DL (2001) Temperature effects on nickel sorption kinetics at the minera-water interface. Soil Sci Soc Am J 65:719-728

Shi T, Jia S, Chen Y, Wen Y, Dua C, Guo H, Wang Z (2009) Adsorption of $\mathrm{Pb}(\mathrm{II}), \mathrm{Cr}$ (III), $\mathrm{Cu}(\mathrm{II}), \mathrm{Cd}(\mathrm{II})$ and $\mathrm{Ni}(\mathrm{II})$ onto a vanadium mine tailing from aqueous solution. J Hazard Mater 169:838-846 
Sthiannopkao S, Sreesai S (2009) Utilization of pulp and paper industrial wastes to remove heavy metals from metal finishing wastewater. J Environ Manage 90:3283-3289

Suresh S, Kamsonlian S, Majumder CB, Chand S, Ramanaiah V, Kumar A (2012) Biosorptive behaviour of mango leaf powder and rice husk for arsenic(III) from aqueous solutions. Int $\mathrm{J}$ Environ Sci Technol 9:565-578

Tripathy SS, Kanungo SB (2005) Adsorption of $\mathrm{Co}^{2+}, \mathrm{Ni}^{2+}, \mathrm{Cu}^{2+}$ and $\mathrm{Zn}^{2+}$ from $0.5 \mathrm{M} \mathrm{NaCl}$ and major ion sea water on a mixture of $\delta-\mathrm{MnO} 2$ and amorphous FeOOH. J Colloid Interf Sci 284:30-38

Unuabonah EI, Adebowale KO, Olu-owolabi BI, Yang LZ, Kong LX (2008) Adsorption of $\mathrm{Pb}$ (II) and Cd (II) from aqueous solutions onto sodium tetraborate-modified Kaolinite clay: equilibrium and thermodynamic studies. Hydrometallurgy 93:1-9

Villaescusa I, Fiol N, Martinez M, Miralles N, Pocj J, Serarols J (2004) Removal of copper and nickel ions from aqueous solutions by grape stalks wastes. Water Res 38:992-1002

Yang X, Yang SB, Yang ST, Hu J, Tan XL, Wang XK (2011) Effect of $\mathrm{pH}$, ionic strength and temperature on sorption of $\mathrm{Pb}(\mathrm{II})$ on
NKF-6 zeolite studied by batch technique. Chem Eng J 168:86-93

Zamani AA, Shokri R, Yaftian MR, Parizanganeh AH (2013) Adsorption of lead, zinc and cadmium ions from contaminated water onto Peganum harmala seeds as biosorbent. Int $\mathbf{J}$ Environ Sci Technol 10:93-102

Zhao X, Zhang G, Jia Q, Zhao C, Zhou W, Li W (2011a) Adsorption of $\mathrm{Cu}(\mathrm{II}), \mathrm{Pb}$ (II), $\mathrm{Co}(\mathrm{II}), \mathrm{Ni}(\mathrm{II})$, and $\mathrm{Cd}$ (II) from aqueous solution by poly (aryl ether ketone) containing pendant carboxyl groups (PEK-L): equilibrium, kinetics, and thermodynamics. Chem Eng J 171:152-158

Zhao G, Li J, Wang X (2011b) Kinetic and thermodynamic study of 1-naphthol adsorption from aqueous solution to sulfonated graphene nano sheets. Chem Eng J 173:185-190

Zhu C, Luan Z, Wang Y, Shan X (2007) Removal of cadmium from aqueous solutions by adsorption on granular red mud (GRM). Sep Purif Technol 57:161-169

Zvinowanda CM, Okonkwo JO, Shabalala PN, Agyei NM (2009) A novel adsorbent for heavy metal remediation in aqueous environments. Int J Environ Sci Technol 6:425-434 